\title{
GEOCHEMISTRY OF ULTRAMAFIC ROCKS FROM THE ULTRAHIGH-PRESSURE METAMORPHIC KIMI COMPLEX IN EAST RHODOPE (NE. GREECE)
}

\author{
Baziotis I. ${ }^{1}$, Mposkos E. ${ }^{1}$, Palikari S. ${ }^{1}$, and Perraki M. ${ }^{1}$ \\ ${ }^{I}$ National Technical University of Athens, School of Mining and Metallurgical Engineering, \\ Division of Geological Sciences, baziotis@metal.ntua.gr,mposkos@metal.ntua.gr, \\ palikari@metal.ntua.gr,maria@metal.ntua.gr
}

\begin{abstract}
In the ultrahigh-pressure metamorphic Kimi Complex garnet-spinel metaperidotites with layers of clinopyroxenites occur. A detailed geochemical investigation using major-trace element relations and major-element modelling indicates that the peridotites represent mantle residues originated after variable melt extraction, along an adiabatic path starting from high- to ultrahigh-pressures. The clinopyroxenites represent HP clinopyroxene-rich cumulates probably formed within the garnet and/or Cr-spinel peridotite stability field.
\end{abstract}

Key words: Metaperidotites, clinopyroxenites, upwelling mantle, partial melting, HP cumulates

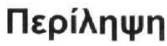

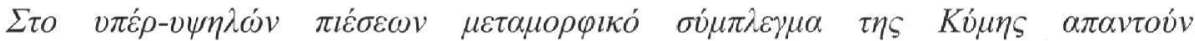

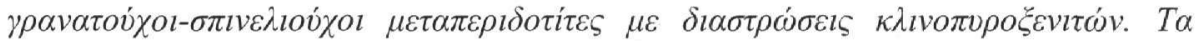

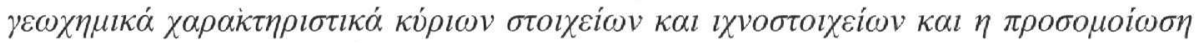

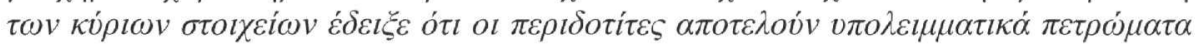

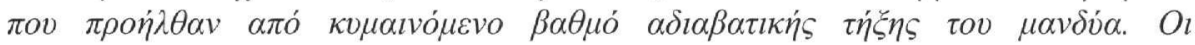

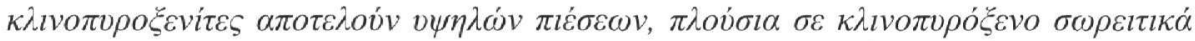

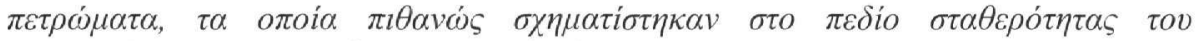

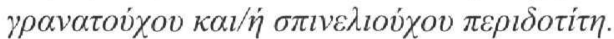

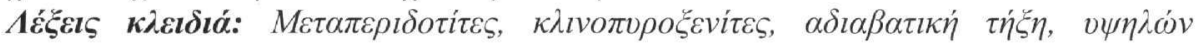
$\pi \imath \varepsilon \dot{\sigma \varepsilon \omega \nu} \sigma \omega \rho \varepsilon i ́ \tau \varepsilon \varsigma$.

\section{Introduction}

In the last decade, several studies have been carried out providing information on the processes occurring in the earth's interior. Geochemical, experimental and petrological studies have been focused on the upper mantle mineralogy, element partitioning, partial melting and generation of primary magmas. Recent studies demonstrate the adiabatic upwelling of the mantle and the formation of aggregate liquids as a result of polybaric melting regime (Asimow et al. 2001).

The origin of orogenic peridotites and the variations in their chemical composition may reflect successive processes such as the partial melting (e.g. Niu 1997) and melt/fluid-rock interaction 
(Rampone and Morten 2001, Hermann et al. 2006, Scambelluri et al. 2006), useful for understanding a multistage petrogenetic history of such rocks. Pyroxenites commonly associated with peridotites are considered to be products of frozen melts (Pearson et al. 1993), melt-rock interaction (Kelemen et al. 1998) and/or cumulate processes (Xu 2002).

In the present work we study the geochemistry of garnet-spinel metaperidotites and associated spinel-garnet clinopyroxenites and olivine clinopyroxenites tectonically emplaced into the crustal rocks of the ultrahigh-pressure (UHP) metamorphic Kimi Complex in Eastern Rhodope. Using geochemical evidences from whole rock major and trace element concentrations, we attempt to answer the following questions:

1. Have the peridotites formed as residuals after batch, fractional or mixed polybaric melting?

2. Which processes are responsible for the formation of the clinopyroxenites?

3. Have the Kimi ultramafic rocks been influenced by post-melting event(s)?

\section{Geological Setting}

The Rhodope Metamorphic Province (RMP) in the easternmost part of the Hellenic Orogen is an Alpine synmetamorphic thrust and nappe complex (e.g. Ricou et al. 1998, Krohe and Mposkos 2002) comprising tectonic slivers of UHP and HP metamorphic rocks (Mposkos and Krohe 2006 and references therein). In Eastern Rhodope, the uppermost metamorphic Kimi Complex, exhumed between 65 and $>48 \mathrm{Ma}$, records an alpine UHP metamorphism followed by a HP granulite/upper amphibolite facies event (Mposkos and Krohe 2006).

The Kimi Complex (Fig. 1) is a tectonic mixture of crustal and mantle rocks. The crustal rocks comprise amphibolitized eclogites, orthogneisses, marbles and migmatitic pelitic gneisses. Diamond inclusions in garnet and rutile needle exsolutions in $\mathrm{Na}$-bearing garnet from the pelitic gneisses document UHP metamorphism with maximum P-T conditions of $>4.5 \mathrm{GPa}$ at $\sim 1000{ }^{\circ} \mathrm{C}$ (Mposkos and Krohe 2006, Perraki et al. 2006).

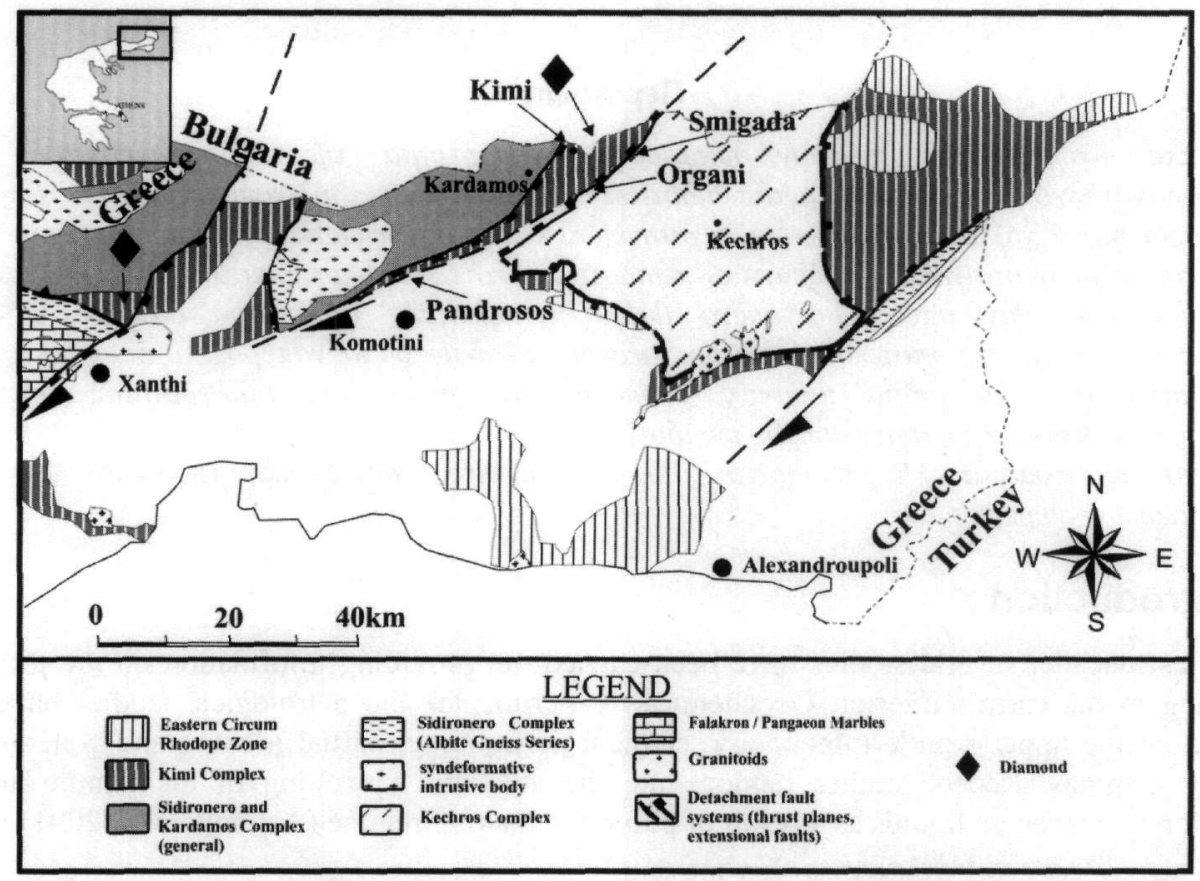

Figure 1 - Geological map of Eastern Rhodope (simplified after Krohe and Mposkos 2002) 
The mantle rocks consist of garnet-spinel metaperidotites, spinel-garnet clinopyroxenites and olivine clinopyroxenites. A garnet-whole rock Sm-Nd age from spinel-garnet clinopyroxenite of $\pm 119 \mathrm{Ma}$ (Wawrzenitz and Mposkos 1997) probably reflects the age of a metamorphic process (at $\sim 1.5 \mathrm{GPa}, \sim 770{ }^{\circ} \mathrm{C}$ ). Muscovite pegmatites with crystallization age of $65-62 \mathrm{Ma}$ intrude all the lithologies (Mposkos and Wawrzenitz 1995, Liati et al. 2002).

\section{Petrography}

\subsection{Garnet-spinel metaperidotites}

Between Organi and Kimi villages (Fig. 1) several bodies of garnet-spinel metaperidotites occur. The mineral assemblage of the metaperidotites is Olivine (Ol)-Clinopyroxene (Cpx)Orthopyroxene (Opx)-Spinel (Spl)-Garnet (Grt)-Hornblende (Hbl). Several pre-, syn- and postdeformation generations of $\mathrm{Spl}, \mathrm{Opx}$ and $\mathrm{Cpx}$ have formed. They are macroscopically characterized by a distinct foliation and lineation defined by flattening of large, older Cpx and Opx grains and elongated recrystallized smaller $\mathrm{Cpx}$ and Opx grain aggregates. Post-deformational mineral assemblages document substantial cooling within the stability field of Cr-spinel-peridotite but still at high pressures as indicated by the garnet exsolutions in clinopyroxene from the associated clinopyroxenites. The formation of hornblende coexisting with olivine indicates influx of water according to the reactions $\mathrm{Grt}+\mathrm{Opx}+\mathrm{H}_{2} \mathrm{O} \rightarrow \mathrm{Ol}+\mathrm{Hbl}$ and $\mathrm{Opx}+\mathrm{Cpx}+\mathrm{Spl}+\mathrm{H}_{2} \mathrm{O} \rightarrow \mathrm{Ol}+\mathrm{Hbl}$, taking place below 1.2-1.3 GPa at $650-750{ }^{\circ} \mathrm{C}$ (Mposkos and Krohe 2006).

\subsection{Spinel-garnet clinopyroxenites and olivine clinopyroxenites}

Clinopyroxenites occur as layers ( $\mathrm{mm}-\mathrm{cm}$ scale, locally $>1 \mathrm{~m}$ wide) within the metaperidotites. Based on the mineral assemblages the clinopyroxenites are subdivided into spinel-garnet clinopyroxenites $(\mathrm{Cpx}+\mathrm{Grt}+\mathrm{Spl}+\mathrm{Hbl} \pm \mathrm{Ol})$ (type-I) and olivine clinopyroxenites $(\mathrm{Cpx}+\mathrm{Ol} \pm \mathrm{Spl})$ (type-II). Garnet inclusions in olivine and clinopyroxene suggest that clinopyroxenites may represent HP mantle cumulates, above the stability field of plagioclase.

\section{Whole rock major and trace element analysis}

Major and trace element compositions of 36 representative samples from metaperidotites (18) and clinopyroxenites (18) were determined by Inductively Coupled Plasma - Emission Spectroscopy (ICP-ES) and X-Ray Fluorescence spectroscopy (XRF), carried out at ACME analytical laboratories in Canada. For major and trace element analyses, structural water was removed from sample powders by heating at $1000{ }^{\circ} \mathrm{C}$ for 1 hour. Major and trace element analyses were performed on solutions after $\mathrm{LiBO}_{2}$ fusion and nitric acid digestion of rock powder for ICP-ES analysis and on prepared beads after mixing with Di-Lithium Tetraborate and fusion for XRF analysis. Rare earth element (REE) analyses were determined by inductively coupled plasma-mass spectroscopy (ICP-MS) after $\mathrm{LiBO}_{2}$ fusion nitric digestion. The chemical compositions of representative samples are presented in table 1.

Table 1 - Representative major and trace element compositions of peridotites (per), type-I and type-II clinopyroxenites (pyx) from the UHP metamorphic Kimi Complex

\begin{tabular}{|c|c|c|c|c|c|c|c|c|c|}
\hline $\begin{array}{l}\text { Sample } \\
\text { Rock }\end{array}$ & $\begin{array}{l}\text { I33 } \\
\text { Per }\end{array}$ & $\begin{array}{r}\text { C4 } \\
\text { Per }\end{array}$ & $\begin{array}{l}\text { C35 } \\
\text { Per }\end{array}$ & $\begin{array}{l}\text { C37 } \\
\text { Per }\end{array}$ & $\begin{array}{r}\text { C31 } \\
\text { Pyx-I }\end{array}$ & $\begin{array}{r}\text { C36 } \\
\text { Pyx-I }\end{array}$ & $\begin{array}{r}\text { 5K29A1 } \\
\text { Pyx-I }\end{array}$ & $\begin{array}{r}\text { 5K26A } \\
\text { Pyx-I }\end{array}$ & $\begin{array}{r}\text { C34 } \\
\text { Pyx-II } \\
\end{array}$ \\
\hline \multicolumn{10}{|c|}{ Major elements $(w t \%)$} \\
\hline $\mathrm{SiO}_{2}$ & 41.60 & 42.71 & 39.49 & 40.02 & 41.25 & 41.44 & 40.25 & 43.67 & 48.71 \\
\hline $\mathrm{TiO}_{2}$ & 0.09 & 0.04 & 0.04 & 0.1 & 0.21 & 0.09 & 0.11 & 0.39 & 0.24 \\
\hline $\mathrm{Al}_{2} \mathrm{O}_{3}$ & 3.52 & 2.39 & 1.23 & 3.19 & 16.88 & 15.55 & 17.32 & 13.29 & 3.92 \\
\hline $\mathrm{Fe}_{2} \mathrm{O}_{3} \mathrm{~T}$ & 10.38 & 8.11 & 10.28 & 9.02 & 7.55 & 9.01 & 9.05 & 8.05 & 4.61 \\
\hline
\end{tabular}


Continue

\begin{tabular}{|c|c|c|c|c|c|c|c|c|c|}
\hline $\mathrm{MnO}$ & 0.09 & 0.12 & 0.13 & 0.1 & 0.11 & 0.28 & 0.33 & 0.26 & 0.14 \\
\hline $\mathrm{MgO}$ & 34.55 & 36.79 & 37.18 & 33.57 & 15.55 & 19.59 & 21.74 & 21.76 & 19.33 \\
\hline $\mathrm{CaO}$ & 2.96 & 2.35 & 1.49 & 2.4 & 16.68 & 9.29 & 6.0 & 7.49 & 18.97 \\
\hline $\mathrm{Na}_{2} \mathrm{O}$ & 0.05 & 0.04 & 0.01 & 0.09 & 0.17 & 0.05 & 0.05 & 0.02 & 0.08 \\
\hline $\mathrm{K}_{2} \mathrm{O}$ & 0.03 & $<0.02$ & $<0.02$ & 0.04 & $<0.02$ & $<0.02$ & 0.04 & 0.04 & $<0.02$ \\
\hline $\mathrm{P}_{2} \mathrm{O}_{5}$ & $<0.01$ & $<0.01$ & $<0.01$ & $<0.01$ & $<0.01$ & $<0.01$ & $<0.01$ & 0.01 & $<0.01$ \\
\hline LOI & 6.59 & 6.6 & 9.2 & 10.8 & 1.3 & 4.2 & 5.0 & 4.8 & 3.4 \\
\hline Total & 99.85 & 99.15 & 99.05 & 99.33 & 99.7 & 99.5 & 99.9 & 99.78 & 99.4 \\
\hline $\mathrm{Mg} \#$ & 0.87 & 0.90 & 0.88 & 0.88 & 0.80 & 0.81 & 0.83 & 0.84 & 0.89 \\
\hline \multicolumn{10}{|c|}{ Trace elements (ppm) } \\
\hline $\mathrm{Ba}$ & 11 & 11 & 5.7 & 6.2 & 16.4 & 6.4 & 23.0 & 11.2 & 3.4 \\
\hline $\mathrm{Nb}$ & 0.8 & $<0.5$ & $<0.5$ & $<0.5$ & 0.5 & $<0.5$ & $<0.5$ & $<0.5$ & 0.5 \\
\hline $\mathrm{Pb}$ & 0.7 & 0.3 & 0.1 & 0.5 & 0.3 & 0.4 & 1.2 & 0.3 & 0.2 \\
\hline $\mathrm{Rb}$ & 1.0 & 0.7 & $<0.5$ & 1.1 & 0.7 & 0.6 & 0.5 & $<0.5$ & 0.5 \\
\hline $\mathrm{Sr}$ & 14.0 & 12.1 & 2.1 & 12.3 & 39.1 & 13.8 & 10.1 & 13.5 & 15.7 \\
\hline V & 79 & 67 & 60 & 94 & 209 & 91 & 113 & 111 & 206 \\
\hline $\mathrm{Zr}$ & 1.5 & 0.5 & 0.5 & 1.6 & 2.4 & 4.2 & 5.9 & 4.9 & 4.6 \\
\hline Y & 2.1 & 1.7 & 0.6 & 1.2 & 4.7 & 7.6 & 6.4 & 13.3 & 9.6 \\
\hline $\mathrm{Ni}$ & 1712 & 1720 & 1722 & 1542 & 87 & 529 & 414 & 665.3 & 461.4 \\
\hline $\mathrm{Cr}$ & 1837 & 2265 & 2087 & 1929 & 575 & 787 & 657 & 1341 & 1403 \\
\hline $\mathrm{La}$ & - & 0.5 & 0.5 & 0.5 & 0.5 & 0.5 & 0.5 & $<.5$ & 0.5 \\
\hline $\mathrm{Ce}$ & - & 0.5 & 0.5 & 1.3 & 0.6 & 1.7 & 1.4 & 0.5 & 1.3 \\
\hline $\operatorname{Pr}$ & - & 0.04 & 0.10 & 0.21 & 0.11 & 0.1 & 0.19 & 0.1 & 0.25 \\
\hline $\mathrm{Nd}$ & - & 0.4 & 0.4 & 1 & 0.5 & 0.6 & 1 & 0.5 & 1.8 \\
\hline $\mathrm{Sm}$ & - & 0.15 & 0.1 & 0.2 & 0.5 & 0.2 & 0.4 & 0.4 & 0.7 \\
\hline $\mathrm{Eu}$ & - & 0.05 & 0.05 & 0.11 & 0.17 & 0.14 & 0.16 & 0.19 & 0.21 \\
\hline Gd & - & 0.13 & 0.09 & 0.3 & 0.63 & 0.7 & 0.75 & 0.84 & 1.1 \\
\hline $\mathrm{Tb}$ & - & 0.03 & 0.02 & 0.06 & 0.13 & 0.17 & 0.15 & 0.29 & 0.25 \\
\hline Dy & - & 0.2 & 0.07 & 0.16 & 0.82 & 1.12 & 1.05 & 2.3 & 1.42 \\
\hline Ho & - & 0.08 & 0.05 & 0.05 & 0.17 & 0.26 & 0.23 & 0.51 & 0.33 \\
\hline $\mathrm{Er}$ & - & 0.19 & 0.07 & 0.09 & 0.47 & 0.76 & 0.62 & 1.54 & 1.04 \\
\hline $\mathrm{Tm}$ & - & 0.05 & 0.05 & 0.05 & 0.08 & 0.09 & 0.09 & 0.23 & 0.12 \\
\hline $\mathrm{Yb}$ & - & 0.28 & 0.11 & 0.1 & 0.48 & 0.67 & 0.48 & 1.1 & 0.91 \\
\hline $\mathrm{Lu}$ & - & 0.03 & 0.01 & 0.02 & 0.06 & 0.09 & 0.07 & 0.2 & 0.14 \\
\hline$[\mathrm{La} / \mathrm{Yb}] \mathrm{N}$ & - & 1.28 & 3.26 & 3.59 & 0.75 & 0.54 & 0.75 & 0.33 & 0.39 \\
\hline$\left[\mathrm{Eu} / \mathrm{Eu}^{*}\right]$ & - & 1.09 & 1.61 & 1.37 & 0.93 & 1.14 & 0.89 & 1.00 & 0.73 \\
\hline
\end{tabular}

$<$ : Below the detection limit. 


\section{Whole Rock Geochemistry}

\subsection{Major elements and compatible trace elements}

\subsubsection{Metaperidotites}

The garnet-spinel metaperidotites have $\mathrm{SiO}_{2}$ content ranging from 43.52-47.91 wt $\%, \mathrm{Al}_{2} \mathrm{O}_{3}$ from 1.37-4.58 wt \%, $\mathrm{CaO}$ from $0.09-3.50 \mathrm{wt} \%$ and $\mathrm{TiO}_{2}$ from $0.02-0.20 \mathrm{wt} \%$. The $\mathrm{Na}_{2} \mathrm{O}$ content varies from $0.01-0.17 \mathrm{wt} \%$, showing wide scattering over a range of $\mathrm{MgO}$ content. $\mathrm{Cr}, \mathrm{Ni}, \mathrm{Co}, \mathrm{V}$ and $\mathrm{Sc}$ abundances range from 1644-3530 ppm, 1283-3000 ppm, 85-137.5 ppm, 25-132 ppm and 2-28 ppm, respectively.

Variations in selected major and trace elements vs. $\mathrm{MgO}$ are shown in figure 2. $\mathrm{CaO}, \mathrm{Al}_{2} \mathrm{O}_{3}, \mathrm{TiO}_{2}$, $\mathrm{Na}_{2} \mathrm{O}$ are negatively correlated to $\mathrm{MgO}$ whereas $\mathrm{Cr}$ and $\mathrm{Ni}$ are positively correlated. The sample $\mathrm{I} 33$ representing the most fertile composition (Tab. 1) displays slightly lower $\mathrm{MgO}, \mathrm{Al}_{2} \mathrm{O}_{3}$ and $\mathrm{CaO}$ content compared to the primitive mantle composition (Sun and McDonough 1989).

\subsubsection{Clinopyroxenites}

The clinopyroxenites have $\mathrm{SiO}_{2}$ content ranging from $40.65-50.74 \mathrm{wt} \%, \mathrm{Al}_{2} \mathrm{O}_{3}$ from $4.08-18.25 \mathrm{wt}$ $\%, \mathrm{CaO}$ from 6.32-19.76 wt $\%$ and $\mathrm{TiO}_{2}$ from $0.07-0.50 \mathrm{wt} \%$. Based on the $\mathrm{Al}_{2} \mathrm{O}_{3}$ content, two types of clinopyroxenites can be distinguished; type- $\mathrm{I}$ with $\mathrm{Al}_{2} \mathrm{O}_{3}$ ranging from 9.48-18.25 wt\% and type-II with $\mathrm{Al}_{2} \mathrm{O}_{3}$ in the range of 4.08-4.80 wt $\%$.
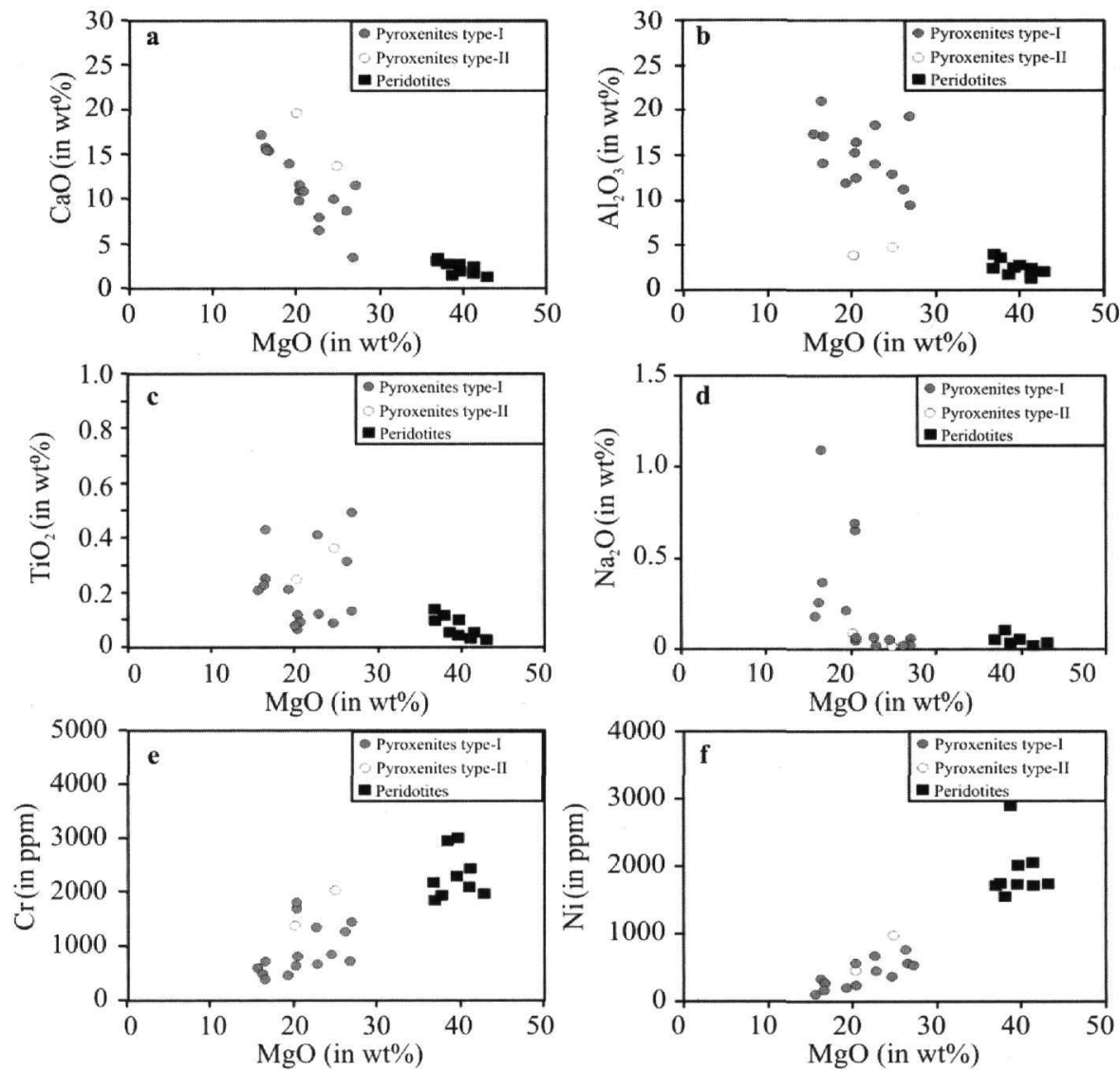

Figure 2 - Variation diagrams of selected elements vs. MgO (anhydrous) of the peridotites and clinopyroxenites from the metamorphic Kimi Complex in East Rhodope 
$\mathrm{CaO}, \mathrm{Al}_{2} \mathrm{O}_{3}, \mathrm{Na}_{2} \mathrm{O}$ and $\mathrm{TiO}_{2}$ generally exhibit a negative correlation with $\mathrm{MgO}$ whereas $\mathrm{Cr}$ and $\mathrm{Ni}$ are positively correlated (Fig. 2). Cr, Ni, Co, V and Sc abundances range from 407.1-1770.6 ppm, 87.3-976.8 ppm, 35.8-75.1 ppm, 51.5-264.2 ppm and 16.6-59.9 ppm, respectively.

\subsection{Incompatible trace elements}

\subsubsection{Metaperidotites}

The primitive-mantle normalized trace element patterns (Fig. 3a) are characterized by relatively flat high field strength elements (HFSE), negative $\mathrm{Zr}$ and positive $\mathrm{Ba}$ anomalies. $\mathrm{Zr} / \mathrm{Zr}^{*}$. $\left[\left(\mathrm{Zr} / \mathrm{Zr}^{*}=\mathrm{Zr}_{\mathrm{N}} /\left(\mathrm{Nd}_{\mathrm{N}} \cdot \mathrm{Sm}_{\mathrm{N}}\right)^{0.5}\right]\right.$ anomalies are negatively correlated with $\mathrm{MgO}$ content (not shown). The rare earth element (REE) patterns normalized to chondrite (Fig. 3b) are characterized by very low REE abundances (1-3x chondrite), light rare earth element (LREE) enrichment $\left[(\mathrm{La} / \mathrm{Yb})_{\mathrm{N}}>1.0\right]$, depletion of $\mathrm{Ce}-\mathrm{Pr}$, slightly negative to positive Eu anomalies $(\mathrm{Eu} / \mathrm{Eu} *=0.87-1.71)$ and relatively flat heavy rare earth element (HREE) patterns.

\subsubsection{Clinopyroxenites}

The primitive-mantle normalized trace element patterns (Fig. 3c) are characterized by negative $\mathrm{Zr}$ and negative to positive anomalies of the large ion lithophile elements (LILE) (e.g. Sr and Ba). They also display relatively flat HFSE patterns with enrichment in elements from Dy to Lu. The relative abundances of HFSE and HREE are higher than those of the metaperidotites.

The chondrite-normalized REE patterns from type-I and type-II clinopyroxenites are illustrated in Figure 3d. Type-I clinopyroxenites are characterized by slightly enriched HREE, depletion of $\operatorname{LREE}\left[(\mathrm{La} / \mathrm{Yb})_{\mathbb{N}}<1.0\right]$, inflection of Ce-Pr in the LREE pattern and slightly negative to positive Eu anomalies $\left(\mathrm{Eu} / \mathrm{Eu}^{*}=0.93-1.14\right)$. Type-II clinopyroxenites are characterized by LREE depletion $\left[(\mathrm{La} / \mathrm{Yb})_{\mathrm{N}}<1.0\right]$, flat HREE's, slightly negative Eu anomaly $\left(\mathrm{Eu} / \mathrm{Eu}^{*}=0.73-0.89\right)$, within the range of $2 \times$ chondrite for LREE and $6 \times$ chondrite for HREE. The REE pattern of the sample 5K29A1 shows a convex-upward segment for the MREE-HREE pattern, similar to that reported for spinel pyroxenites from Qilin Island, South China (Xu et al. 2002).
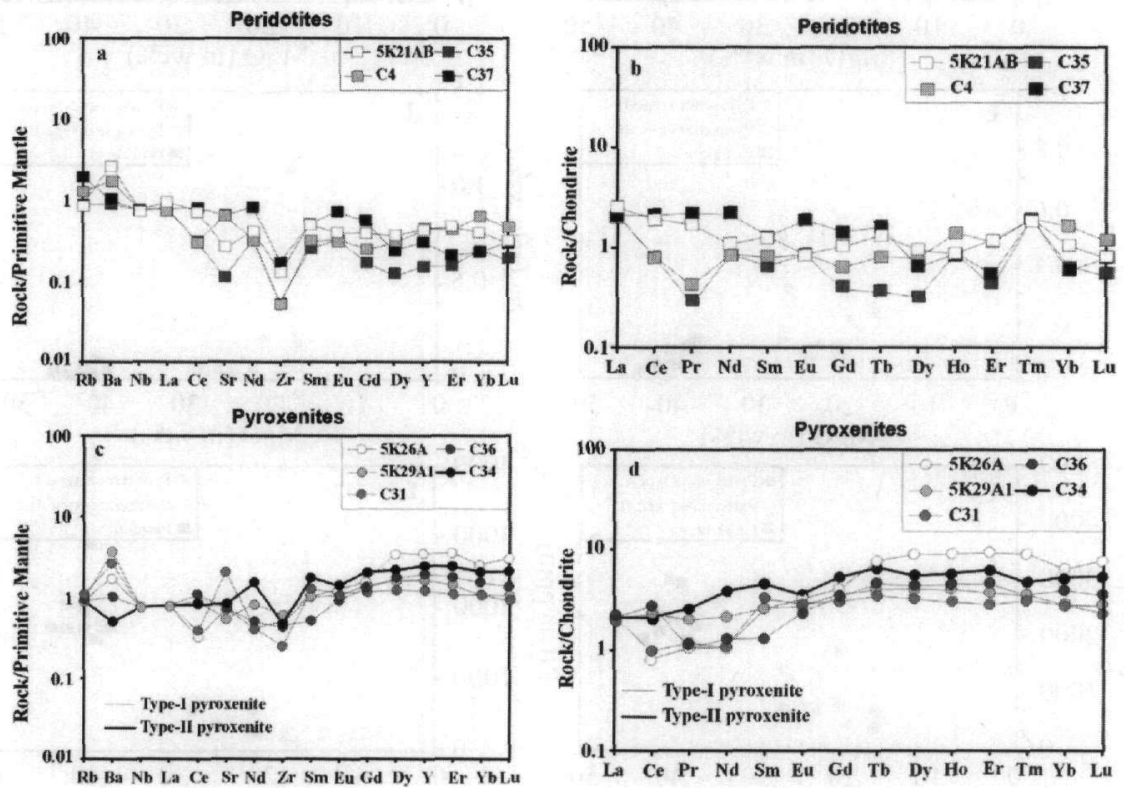

Figure 3 - Primitive-mantle and chondrite-normalized incompatible element and REE patterns for peridotites $(a, b)$ and clinopyroxenites $(c, d)$. Normalizing values are from Sun and McDonough (1989) 


\section{Discussion}

\subsection{Do the peridotites represent residues after variable degree of partial melting?}

Partial melting is an important process for the formation of mantle rocks; mantle rocks may represent residues after variable degree of melt extraction (Frey et al. 1985).

The observed variations of major elements vs. $\mathrm{MgO}$ in the studied peridotites are widely ascribed to extraction of melts from a fertile protolith subjected to different degree of partial melting, where the peridotite represents the residual material (Frey et al. 1985). Besides, the gradual increase in $\mathrm{Zr} / \mathrm{Zr}^{*}$ anomaly observed in the metaperidotite samples is consistent with variable degree of melt extraction (Yu et al. 2006).

\subsubsection{Geochemical modelling}

Trying to constrain the melting regime of the Kimi peridotites we simulated the major element variations testing two different melting models, the batch and the fractional melting. Both melting models were tested for polybaric conditions for pressures ranging from 4 to $1 \mathrm{GPa}$. Batch and fractional melting were modelled for the most fertile peridotite (sample I33; Table 1) using the program Adiabat_1ph, a simple text-menu driver for subroutine versions of the algorithms MELTS, pMELTS and phMELTS (Asimow et al. 2004 and references therein). pMELTS was used to illustrate batch and fractional melting and calculate the produced liquids and residues. The two melting regimes were carried out under isentropic conditions and at the same potential temperatures following the method described by Asimow et al. (2001). In both cases, melting continues up to $1 \mathrm{~atm}$ in order to produce aggregate liquids that will be used later as the possible primary sources to explain the cumulate character of the clinopyroxenites.

\section{A. Batch Melting}

In figure 4 selected major elements vs. $\mathrm{MgO}$ and pMELTS calculations of residues for polybaric batch melting under isentropic conditions are plotted. We used two different mantle states in our calculations, a "hot" and a "cold" case, but only the "hot" one is projected ("hot" mantle at 3.5 $\mathrm{GPa} / \mathrm{T}_{\mathrm{p}}=1480^{\circ} \mathrm{C}$ and "cold" mantle at $\left.1.5 \mathrm{GPa} / \mathrm{T}_{\mathrm{p}}=1391^{\circ} \mathrm{C}\right)$.
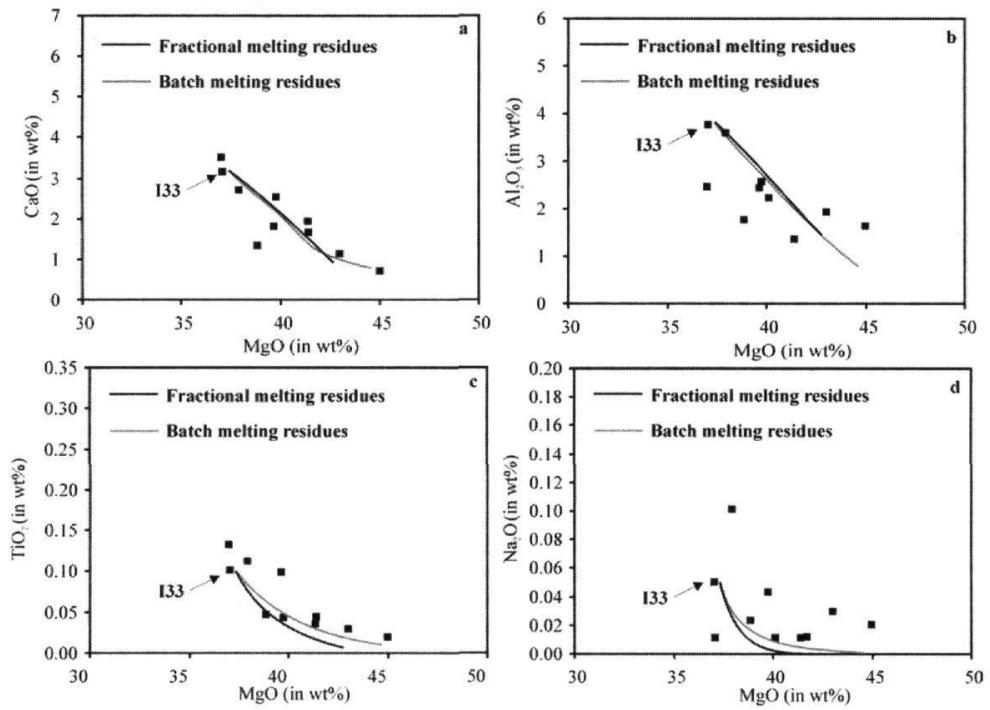

Figure 4 - (a-d) Calculated residue trends after isentropic polybaric batch and fractional melting of a fertile peridotite (sample I33). Peridotite symbols as in figure 2 
As mentioned above (Cp. 5.1.1), the peridotites, despite some scattering, exhibit a general negative trend of $\mathrm{CaO}$ and $\mathrm{Al}_{2} \mathrm{O}_{3}$ with $\mathrm{MgO}$ content. The calculated residues reproduce the overall negative trend of $\mathrm{CaO}$ and $\mathrm{Al}_{2} \mathrm{O}_{3}$. $\mathrm{TiO}_{2}$ and $\mathrm{Na}_{2} \mathrm{O}$ trends are slightly lower at a given $\mathrm{MgO}$ content, probably due to the low $\mathrm{TiO}_{2}$ and $\mathrm{Na}_{2} \mathrm{O}$ contents in the selected source. The degree of melting is positively correlated with pressure $(0-26.5 \%$ with mean melt fraction at $\sim 9 \%$ at $\mathrm{P} \sim 2 \mathrm{GPa})$.

\section{B. Fractional Melting}

The calculated fractional melting residues (Fig. 4) reproduce the major-element compositions similarly to the polybaric batch melting. $\mathrm{CaO}$ and $\mathrm{Al}_{2} \mathrm{O}_{3}$ trends are similar to those of polybaric batch melting whereas those of $\mathrm{TiO}_{2}$ and $\mathrm{Na}_{2} \mathrm{O}$ lie at lower values. The calculated $\mathrm{MgO}$ content failed to reach the most refractory peridotites, even at the "hot" mantle state $\left(\mathrm{T}_{\mathrm{p}}=1480{ }^{\circ} \mathrm{C}\right)$. The degree of melting is extended up to $0.3 \%$ at $\sim 1.3 \mathrm{GPa}$. The mean values of melting extent and melting pressure for the "hot" mantle case are $11.6 \%$ and $\sim 2 \mathrm{GPa}$, respectively. The "cold" mantle case yields higher mean extent of melting $(\sim 14.3 \%)$ at lower mean pressure $(\sim 1.1 \mathrm{GPa})$.

\section{Batch melting, fractional melting or combination?}

The two melting models, batch and fractional melting, yield similar results. Both the two melting regimes may broadly explain the natural peridotite data from the Kimi Complex. Thus, in order to clarify the predominant process, we used the sensitive to melting process $\mathrm{CaO} / \mathrm{Al}_{2} \mathrm{O}_{3}$ and $\mathrm{TiO}_{2} / \mathrm{Al}_{2} \mathrm{O}_{3}$ ratios. They can also reflect source heterogeneities or a possible olivine-addition event.

The calculated $\mathrm{CaO} / \mathrm{Al}_{2} \mathrm{O}_{3}$ ratios (Fig. 5a) remain relatively constant at a range from $\sim 0.8$ to $\sim 0.9$, for both batch and fractional melting regimes. However, the peridotite data shows a considerable scattering in the $\mathrm{CaO} / \mathrm{Al}_{2} \mathrm{O}_{3}$ ratios not following the calculated ones. The produced $\mathrm{TiO}_{2} / \mathrm{Al}_{2} \mathrm{O}_{3}$ ratios are higher in batch melting compared to those of the fractional melting (Fig. $5 \mathrm{~b}$ ). As outlined by Asimow (1999) it is difficult to consider if batch or fractional melting is predominant in order to explain the variations of these ratios. He suggests a combination of fractional followed by batch melting or vice versa, to decipher the bulk composition of abyssal peridotites. Such data, unless it is ought to analytical uncertainties, could also be the result of source heterogeneity or minor olivine-addition, which might have occurred after fractional crystallization of migrating liquids.

In the case of Kimi peridotites, a polybaric melting model starting at high- to ultrahigh- pressures and continuing adiabatically at lower pressures is efficient to explain the peridotite compositions. We advocate a mixed melting regime, similar to that of Asimow (1999), with a potential role of the fractional melting component in order to explain the range of the $\mathrm{CaO} / \mathrm{Al}_{2} \mathrm{O}_{3}$ and $\mathrm{TiO}_{2} / \mathrm{Al}_{2} \mathrm{O}_{3}$ ratios and the $\mathrm{MgO}$ content of the Kimi peridotites. The mean extent of melting, deduced from the two models, ranges from $\sim 9 \%$ to $\sim 11.6 \%$ at pressure of $\sim 2 \mathrm{GPa}$.
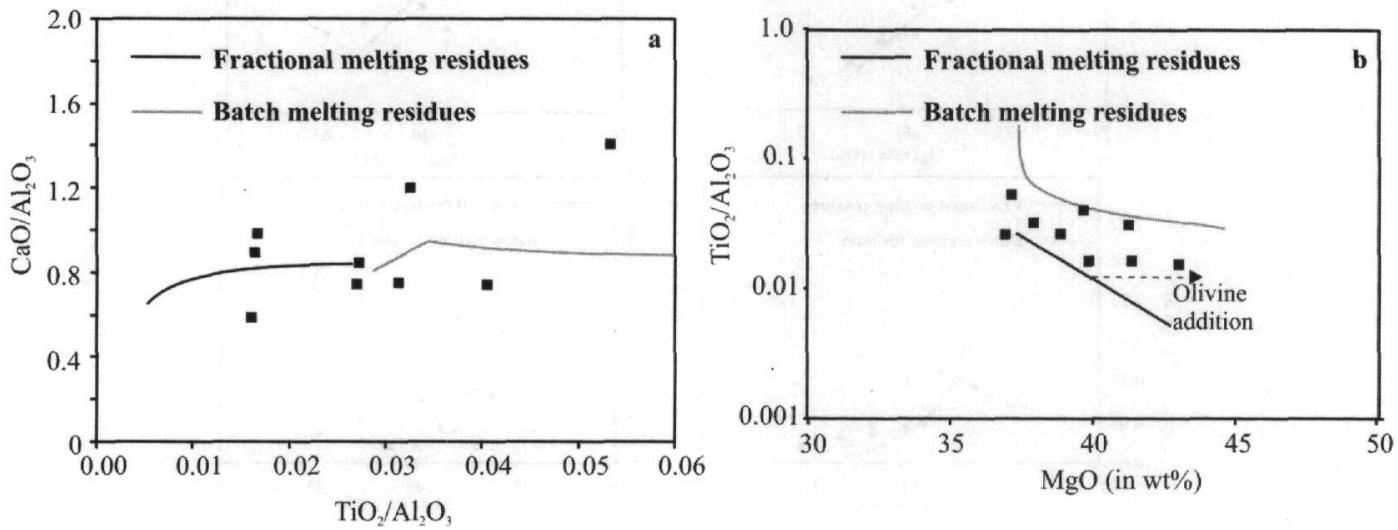

Figure 5 - (a) $\mathrm{CaO} / \mathrm{Al}_{2} \mathrm{O}_{3}$ vs $\mathrm{TiO}_{2} / \mathrm{Al}_{2} \mathrm{O}_{3}$ and (b) $\mathrm{TiO}_{2} / \mathrm{Al}_{2} \mathrm{O}_{3}$ (log scale) vs $\mathrm{MgO}$ for calculated residues and peridotite data. Olivine addition vector is also shown 


\subsection{Processes accounting for the formation of clinopyroxenites}

\subsubsection{Frozen melts}

Experimental and calculated melts are compared to natural data to test the possibility of clinopyroxenites representing frozen melts derived from partial melting of host peridotite. We compare the Kimi clinopyroxenites to the experimental melts produced by partial melting of peridotites under various pressures using different experimental datasets (Hirose and Kushiro 1993, Bulatov et al. 2002). Then, the calculated melts produced after partial melting of peridotite (Cp. 6.1) are quoted testing a possible relation of the host peridotites and the associated clinopyroxenites.

The Kimi clinopyroxenites exhibit lower $\mathrm{TiO}_{2}$ and $\mathrm{SiO}_{2}$ at a given $\mathrm{MgO}$ content compared to the experimental melts. The $\mathrm{CaO}$ content of the experimental melts firstly increases and then decreases with decreasing $\mathrm{MgO}$ whereas the $\mathrm{Al}_{2} \mathrm{O}_{3}$ displays a linearly negative trend with the $\mathrm{MgO}$ content. In the Kimi clinopyroxenites, the $\mathrm{CaO}$ and $\mathrm{Al}_{2} \mathrm{O}_{3}$ contents increase with decreasing $\mathrm{MgO}$ content. Similar trends to the studied clinopyroxenites, regarding the $\mathrm{CaO}$ content, provide the experimental dataset by Bulatov et al. (2002). Evaluating the results of Bulatov et al. (2002) and comparing the experimental dataset to the studied one, we conclude that the $\mathrm{CaO}$ trend of the natural clinopyroxenites, though it is parallel to the experimental one, it is shifted toward higher $\mathrm{MgO}$ content. Moreover, the $\mathrm{MgO}$ content is positively correlated with pressure and melting degree indicating that if the clinopyroxenites represented liquid compositions they should have been formed under very high pressure ( $>2 \mathrm{GPa}$ ) and high degree of melting $(>>30 \%)$. However, even at such pressures and extensive degree of melting, the other major elements failed to fit the natural data.

We have advocated a mixed melting model to explain the Kimi peridotites as residues after liquid extraction during adiabatic upwelling of the mantle. The respective liquids failed to fit the major element compositions of the Kimi clinopyroxenites (Figs 6a-d). In particular, the calculated melts display lower $\mathrm{CaO}, \mathrm{Al}_{2} \mathrm{O}_{3}$ and $\mathrm{SiO}_{2}$ at a given $\mathrm{MgO}$ content (Figs $6 \mathrm{a}$,b,d). The $\mathrm{TiO}_{2}$ content of the calculated melts displays a rather steep positive trend vs. $\mathrm{MgO}$ content (Fig. 6c). On the contrary, the Kimi clinopyroxenites, despite some scattering, display a negative correlation between $\mathrm{TiO}_{2}$ and $\mathrm{MgO}$ contents.

Summing up, the clinopyroxenite compositions failed to fit the experimental and calculated melt compositions under high-pressure conditions. Therefore, they cannot represent frozen melts produced by partial melting of the peridotite.

\subsubsection{Melt-rock interaction}

The Kimi clinopyroxenites may alternatively represent the products of melt/rock interaction between a silicic melt and the host peridotite. In this case, the compatible elements are always controlled by the peridotite composition. Thus, the melt/rock interaction products should have had high $\mathrm{Ni}$ contents and a range of $\mathrm{Mg} \#$ similar to that of peridotites.

Both types of clinopyroxenites (type-I and type-II) show highly variable $\mathrm{Ni}$ and $\mathrm{Sc}$ contents, lower than those of the host peridotites and a wide range of $\mathrm{Mg} \#(0.76-0.89)$. The $\mathrm{Ni}$ and $\mathrm{Sc}$ contents are positive correlated with the $\mathrm{Mg \#}$. The non-uniformity of $\mathrm{Ni}$ and $\mathrm{Sc}$ contents and the wide range of $\mathrm{Mg} \#$ preclude interaction between a silicic melt and the host peridotite. If the clinopyroxenites had represented such products, then, the compatible elements content should have been inherited by the peridotites. However, this is not the case of the Kimi clinopyroxenites.

\subsubsection{High-pressure cumulates}

Another important process to illustrate the origin of the Kimi clinopyroxenites is the crystal segregation at high pressures $(\mathrm{Xu} 2002)$. This hypothesis is treated through major-trace element relations and geochemical modelling. 

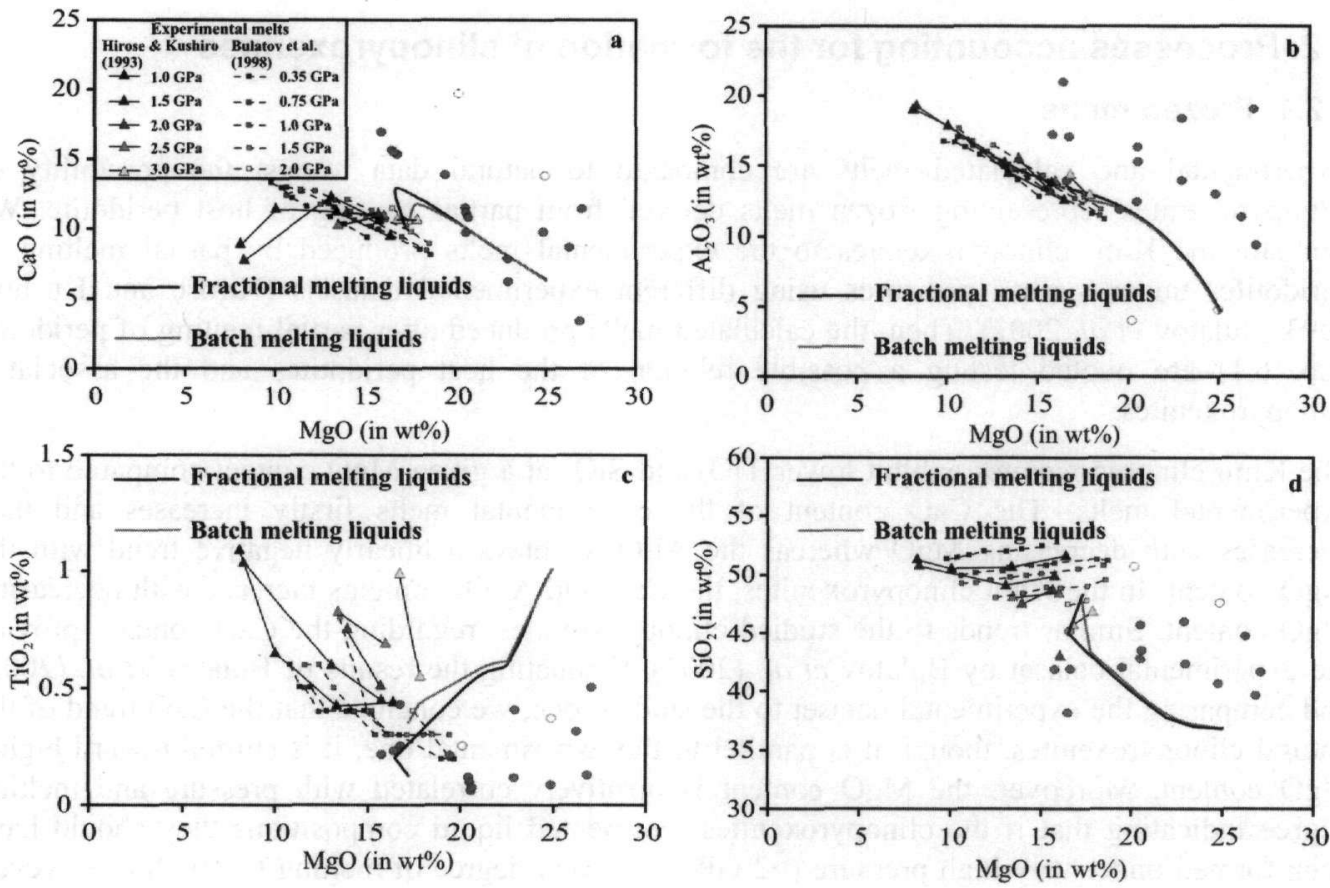

Figure 6 - (a-d) Experimental and calculated melt compositions of major elements vs. MgO. The experimental melt compositions are obtained after partial melting of peridotite at various pressures (Hirose and Kushiro 1993, Bulatov et al. 2002). The calculated trends are obtained after polybaric melting of fertile peridotite (sample 133). We project the calculated melts at the "hot" mantle state $\left(P_{0}=3.5 G P a\right.$ and $\left.T_{p}=1480^{\circ} \mathrm{C}\right)$. Symbols as in figure 2

Type-I (Al-rich) clinopyroxenites are enriched in the incompatible elements $\mathrm{Ba}, \mathrm{Sr}, \mathrm{Na}$ and $\mathrm{K}$ and present variable LREE and HREE-enrichments. Two different REE patterns are observed, a convex and a concave. These features are typical of cumulate origin of the clinopyroxenites. The distinct REE patterns indicate spinel-rich cumulates. However, the slightly HREE-enriched pattern of the clinopyroxenite sample 5K26A (Fig. 3) indicates that garnet was also present. Additionally, the garnet inclusions in olivine and clinopyroxene support the clinopyroxenite formation within the garnet stability field. Type-II clinopyroxenites (e.g. sample C34) show relatively high LREE contents, convex REE pattern and variable Ni content, typical of clinopyroxene-rich cumulates derived from magma of basaltic composition (Liu et al. 2005). Both types of clinopyroxenites show no distinct positive Eu anomaly, indicating that plagioclase was not a cumulus phase.

For the geochemical modelling, primary liquid compositions, obtained from polybaric (batch and fractional) melting modelling, are used as possible sources prior to cumulate process of clinopyroxenites. The geochemical modelling of major-element compositions of type-I clinopyroxenites is based on melts compositions, obtained from the batch and fractional melting modelling. We used pMELTS algorithm through the software Adiabat 1ph to illustrate batch and fractional crystallization of the liquids, produced after peridotite melting. Figure 7 shows the calculated major-element compositions after isobaric crystallization at various pressures. $\mathrm{CaO}$, $\mathrm{Al}_{2} \mathrm{O}_{3}$ and $\mathrm{TiO}_{2}$ are negatively correlated with $\mathrm{MgO}$. $\mathrm{TiO}_{2}$ content of the Kimi clinopyroxenites lies over the calculated trend because of the $\mathrm{TiO}_{2}$ depleted nature of the used source. However, despite some scattering, the clinopyroxenite compositions are rather well fitted by the calculated crystallization products (Fig. $7 \mathrm{a}-\mathrm{d}$ ) at a pressure interval $1.0-1.5 \mathrm{GPa}$. The appropriate melt to produce the Kimi clinopyroxenites has a high-Mg basaltic composition. 

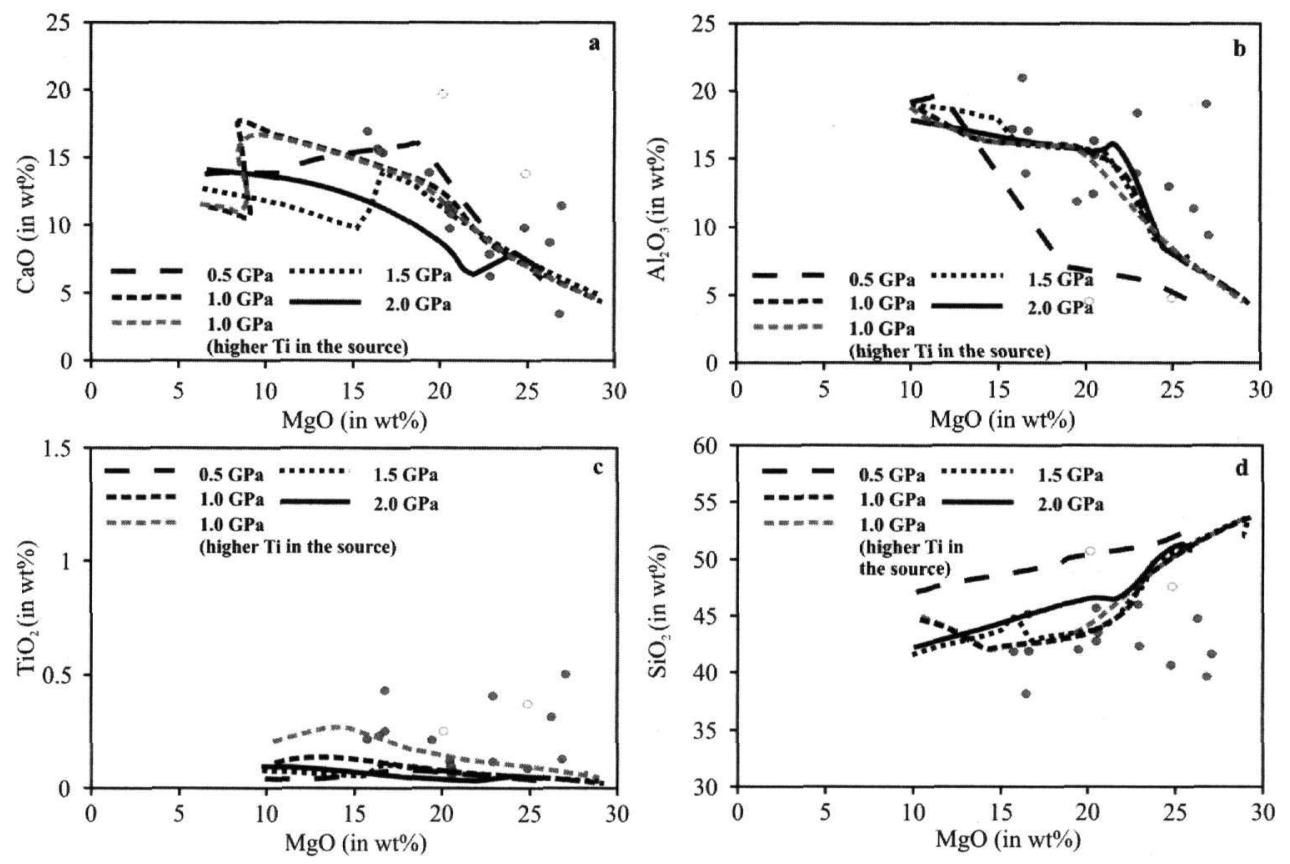

Figure 7 - (a-d) Calculated major-element compositions obtained after isobaric crystallization of liquids derived by polybaric melting. A primary, high-Mg, near basaltic composition has been used as the initial source. Moreover, a slightly Ti-rich source is used, in order to visualize better, the $\mathrm{TiO}_{2}$ content of the Kimi clinopyroxenites. Symbols as in figure 2

In sum, major-trace element relations and geochemical modelling suggest that the Kimi clinopyroxenites are neither frozen melts nor melt/peridotite interaction products but they represent clinopyroxene-rich cumulates formed at pressures $>1.0 \mathrm{GPa}$.

\subsection{Post-melting metasomatic event}

Geochemical features, observed in both peridotites and pyroxenites suggest a metasomatic event. Type-I pyroxenites are enriched in the incompatible elements $\mathrm{Ba}$ and $\mathrm{Sr}$ and show an inflection of $\mathrm{Ce}$ in the LREE patterns. Similar incompatible and REE patterns, but with lower absolute abundances share the peridotites (e.g. Sample C4). The enrichment is commonly attributed to chromatographic effect of melt percolation (Navon and Stolper 1987).

Three scenarios can be advocated to explain the sources for the metasomatic signature observed in peridotites and pyroxenites (type-I); (1) in the mantle wedge due to interaction with melts (fluids), incompatible elements (LILE and LREE) are liberated by a subsiding slab (Scambelluri et al. 2006), (2) at the site of crystallization of pyroxenites, residual melts might have interacted with the pyroxenites and peridotites (Xu et al. 2002), and (3) fluid-influx from the surrounding continental rocks (migmatites; see Mposkos and Krohe 2006). In cases 1 and 3, amphibole is the major carrier of the LILE and LREE (Hermann et al. 2006). The first and third scenarios are adequate mechanisms to explain the widespread enrichment in incompatible element (LILE and LREE) and subsolidus amphibole formation.

\section{Conclusions}

The ultramafic rocks of the UHP metamorphic Kimi Complex consist of peridotites with clinopyroxenite layers. The metaperidotites most probably represent residual compositions after variable degree of melt extraction. Melting modelling suggests a combined (fractional followed by 
batch melting and vice versa) polybaric melting model starting at high- to ultrahigh- pressures and continuing adiabatically at lower pressures. The clinopyroxenites represent HP clinopyroxene-rich cumulates crystallized within the garnet and/or Cr-spinel peridotite stability field. Selective samples from both peridotites and pyroxenites share a geochemical signature, featuring the enrichment in LREE and LILE, implying a regional metasomatic event.

\section{Acknowledgements}

We want to express our sincere thanks to J. Hermann for his critical and constructive review. P.D.Asimow is thanked for his constructive comments about the software Adiabat_1ph.

\section{References}

Asimow, P.D., 1999. A model that reconciles major- and trace- element data from abyssal peridotites, Earth and Planetary Science Letters, 169, 303-319.

Asimow, P.D., Hirschmann, M.M., and Stolper, E.M., 2001. Calculation of peridotite partial melting from thermodynamic models of minerals and melts. IV. Adiabatic decompression and the composition and mean properties of mid-ocean ridge basalts, Journal of Petrology, 42, 963-998.

Asimow, P.D., Dixon, J.E., and Langmuir, C.H., 2004. A hydrous melting and fractionation model for mid-ocean ridge basalts: Application to the Mid-Atlantic Ridge near the Azores, Geochemistry Geophysics Geosystems, 5, art. no. Q01E16, DOI: 10.1029/2003GC000568.

Bulatov, V.K., Girnis, A.V., and Brey, G.P., 2002. Experimental melting of a modally heterogeneous mantle, Mineralogy and Petrology, 75, 131-152.

Frey, F.A., Suen, C.J., and Stockman, H.W., 1985, The Ronda high temperature peridotite: Geochemistry and petrogenesis, Geochimica et Cosmochimica Acta, 49, 2469-2491.

Hermann, J., Rubatto, D., and Trommsdorff, V. 2006. Sub-solidus Oligocene zircon formation in garnet peridotite during fast decompression and fluid infiltration (Duria, Central Alps), Mineralogy and Petrology, 88, 181-206.

Hirose, K., and Kushiro, I., 1993. Partial melting of dry peridotites at high pressures: determination of compositions of melts segregated from peridotite using aggregates of diamond, Earth and Planetary Science Letters, 114, 477-489.

Kelemen, P.B., Hart, S.R., and Bernstein, S., 1998. Silica enrichment in the continental upper mantle via melt/rock reaction, Earth and Planetary Science Letters, 164, 387-406.

Krohe, A., and Mposkos, E., 2002. Multiple generations of extensional detachments in the Rhodope Mountains (N.Greece): evidence of episodic exhumation of high-P rocks. In D.J. Blundell, G. Neubauer and A. Von Quant (eds), The timing and location of major ore deposits in an evolving orogen. Geol. Soc. Sp. Publ., London, 204, 151-178.

Liati, A., Gebauer, D., and Wysoczanski, R., 2002. U-Pb SHRIMP-dating of zircon domains from UHP mafic rocks in the Rhodope zone (N'Greece); evidence for Early Cretaceous crystallization and Late Cretaceous metamorphism, Chemical Geology, 184, 281-300.

Liu, Y., Gao, S., Aeolus Lee, C.-T., Hu, S., Liu, X., and Yuan H., 2005. Melt-peridotite interactions: Links between garnet pyroxenite and high-Mg\# signature of continental crust, Earth and Planetary Sciences Letters, 234, 39-57.

Mposkos, E., and Wawrzenitz, N., 1995. Metapegmatites and pegmatites bracketing the time of HP-metamorphism in polymetamorphic rocks of the E-Rhodope: Petrological and 
geochronological constraints, XV Con of the Carpatho-Balkan Geol. Assoc. Geol. Soc. Sp. Publ, Greece, 2, 602-608.

Mposkos, E., and Krohe, A., 2006. Pressure-Temperature-deformation paths of closely associated ultra-high-pressure (diamond-bearing) crustal and mantle rocks of the Kimi Complex: implications for the tectonic history of the Rhodope Mountains, northern Greece, Canadian Journal of Earth Sciences, 43, 1755-1776.

Navon, O., and Stolper, E., 1987. Geochemical consequence of melt percolation: the upper mantle as a chromatographic column, Journal of Geology, 95, 285-307.

Niu, Y., 1997. Mantle melting and melt extraction processes beneath ocean ridges: Evidence from abyssal peridotites, Journal of Petrology, 38, 1047-1074.

Pearson, D.G., Davies, G.R., and Nixon, P.H., 1993. Geochemical constraints on the petrogenesis of diamond Facies Pyroxenites from the Beni Bousera Peridotite Massif, North Morocco, Journal of Petrology, 34, 125-172.

Perraki, M., Proyer, A., Mposkos, E., Kaindl, R., and Hoinkes, G., 2006. Raman microspectroscopy on diamond, graphite and other carbon polymorphs from the ultrahighpressure metamorphic Kimi Complex of the Rhodope Metamorphic Province, NE Greece, Earth and Planetary Science Letters, 241, 672-685.

Rampone, E., and Morten, L., 2001. Records of crustal metasomatism in the garnet peridotites of the Ulten Zone (Upper Austroalpine, Eastern Alps), Journal of Petrology, 42, 207-219.

Ricou, L.E., Burg, J.P., Godfriaux, I., and Ivanov, Z., 1998. Rhodope and Vardar: the metamorphic and olistostromic paired belts related to Cretaceous subduction under Europe, Geodynamica Acta, 11, 285-309.

Scambelluri, M., Hermann, J., Morten, L., and Rampone, E., 2006. Melt-versus fluid-induced metasomatism in spinel to garnet wedge peridotites (Ulten Zone, Eastern Italian Alps): clues from trace element and Li abundances, Contributions to Mineralogy and Petrology, DOI: $10.1007 / \mathrm{s} 00410-006-0064-9$.

Sun, S.S., and McDonough, W.F., 1989. Chemical and isotopic systematics of oceanic basalts: implications for mantle composition and process. In A.D. Saunders and J.M. Norry (eds), Magmatism in Ocean Basins. Geol. Soc. Sp. Publ., London, 42, 313-345.

Wawrzenitz, N., and Mposkos, E., 1997. First evidence for lower Cretaceous HP / HTmetamorphism in the Eastern Rhodope, North Aegean Region, North-East Greece, European Journal of Mineralogy, 9, 659-664.

Xu, Y.G., 2002. Evidence for crustal components in the mantle and constraints on crustal recycling mechanisms: pyroxenite xenoliths from Hannuoba, North China, Chemical Geology, 182, 301-322.

Xu, Y.G., Sun, M., Yan, W., Liu, Y., Huang, X.L., and Chen X.M., 2002. Xenolith evidence for polybaric melting and stratification of the upper mantle beneath South China, Journal of Asian Earth Sciences, 20, 937-954.

Yu, J.-H., O'Reilly, S.Y., Zhang, M., Griffin, W.L., and Xu, X., 2006. Roles of melting and metasomatism in the formation of the lithospheric mantle beneath the Leizhou peninsula, South China, Journal of Petrology, 47, 355-383. 